\title{
PERCHLOROETHYLENE: ACUTE OCCUPATIONAL POISONING AND A PROPOSAL FOR ITS REPLACEMENT WITH OTHER LESS TOXIC SUBSTANCES
}

\author{
Pere Sanz-Gallen ${ }^{1}$, Albert Sanz-Ribas ${ }^{1}$, Gabriel Martí-Amengual ${ }^{1}$, Jaime Fernández-Colomé \\ ${ }^{1}$ University of Barcelona, Barcelona, Spain \\ Faculty of Medicine and Health Sciences, Department of Medicine, Unit of Occupational Medicine and Toxicology \\ ${ }^{2}$ Echevarne Laboratory, Barcelona, Spain \\ Toxicology and Bioanalysis Unit
}

\begin{abstract}
Perchloroethylene is used mainly as a solvent in dry cleaning, cleaning of electrical equipment, and degreasing of metal parts. The authors report a case of acute poisoning with perchloroethylene contracted by a maintenance worker when cleaning an electric transformer. Since perchloroethylene may cause severe poisoning and the International Agency for Research on Cancer has classified it as a probable carcinogen for humans, the authors have revised the main substances that may replace perchloroethylene in the workplace. Med Pr. 2019;70(3):393-5

Key words: perchloroethylene, chlorinated solvents, acute occupational poisoning, occupational medicine, alternatives to perchloroethylene, preventive measures

Corresponding author: Pere Sanz-Gallen, University of Barcelona, Faculty of Medicine and Health Sciences, Department of Medicine, Unit of Occupational Medicine and Toxicology, Casanova 143, 08036 Barcelona, Spain, e-mail: 17039psg@comb.cat

Received: May 17, 2018, accepted: October 30, 2018
\end{abstract}

\section{INTRODUCTION}

Perchloroethylene (tetrachloroethylene) is a colorless volatile liquid, used mainly as a solvent in dry cleaning, cleaning of electrical equipment, and degreasing of metal parts.

The authors report a case of acute occupational poisoning with perchloroethylene, review its possible effects on health, and assess the properties of other substances that have been proposed as replacements [1-3].

\section{CASE REPORT}

A 32-year-old man had worked for 6 years in the maintenance unit of an electrical company. After $15 \mathrm{~min}$ of cleaning an electric transformer located underground he lost consciousness. He was quickly rescued by 2 colleagues and taken to a nearby hospital where he was admitted to the intensive care unit (ICU). His Glasgow Coma Scale (GCS) score was 2 and he presented acute respiratory failure that required tracheal intubation and assisted ventilation for 5 days. Seven days after the poisoning, he was discharged from hospital without any sequelae.
The chest X-ray, cranial CT and the general analytical parameters were within normal ranges. The concentration of perchloroethylene in blood on admission was $16 \mathrm{mg} / \mathrm{l}$ (the biological limit value in Spain: $0.4 \mathrm{mg} / \mathrm{l}$ [4]). The investigation revealed that the solvent used was perchloroethylene. The environmental concentration was $3400 \mathrm{ppm}$ (the threshold limit value in Spain: time-weight average [TWA] of $20 \mathrm{ppm}$ and the shortterm exposure limit [STEL] of $40 \mathrm{ppm}$ [4]); the worker wore personal protective clothing, although this was not enough to avoid acute poisoning (he wore a mask with an activated carbon filter while working in a confined space but did not use autonomous breathing equipment).

\section{DISCUSSION}

\section{Comments on the case report}

Perchloroethylene may be absorbed through the digestive and respiratory tracts, and through the skin. Most of the perchloroethylene absorbed is eliminated by the exhaled air. Only around $10 \%$ is metabolized, and the major urinary metabolite is trichloroacetic acid. 
Perchloroethylene vapor irritates the skin and mucous membranes. Concentrations higher than 2000 ppm may cause central nervous system depression and acute lung edema of non-cardiogenic origin [5]. Cases of fatal acute poisoning after inhalation of perchloroethylene have been reported, with blood perchloroethylene concentrations between $44 \mathrm{mg} / \mathrm{l}$ and $158 \mathrm{mg} / \mathrm{l}$ being detected in the body [6-8]. Chronic exposure to perchloroethylene may produce neuro-psychological alterations (fatigue, dizziness, impaired memory and alcohol intolerance) [5], and may also cause liver and kidney alterations $[9,10]$.

\section{Comments on other alternatives for replacing perchloroethylene}

The main primary prevention measure should be to replace perchloroethylene with other chemical substances and/or industrial processes that entail a lower risk to health [1-3].

For use as a degreaser of metal parts in "cold" applications, perchloroethylene may be replaced with aliphatic hydrocarbons. Solvents of plant origin such as d-limonene (CAS No. 5989-27-5) may also be used. For cleaning electrical equipment, a solvent based on hydrochlorofluorocarbon, the HCFC-141b with CAS No. 1715-00-6 (1,1-dichloro-1-fluoroethane) [1,2] may be used.

The main use of perchloroethylene is that of a solvent in dry cleaning. The main chemicals and industrial processes used as replacements for perchloroethylene are wet cleaning, liquid carbon dioxide, aliphatic hydrocarbons, acetal (CAS No. 2568-90-3), propylene glycol ethers, cyclic volatile methyl siloxane (D5) with CAS No. 541-02-6) and n-propyl bromide (CAS No. 106-94-5)3.

The main health effects which substances that replace perchloroethylene may cause are as follows:

1. Aliphatic hydrocarbons may cause chemical pneumonitis in the lung, and those that are volatile may cause acute central nervous system effects, and/or ocular and respiratory irritation [11].

2. D-Limonene is a skin irritant and a potential sensitizer for humans [12].

3. HCFC $141 \mathrm{~b}$ is mildly irritating to the eye. High concentrations of HCFC $141 \mathrm{~b}$ in the heart raise the likelihood of cardiac tropism and may induce sudden death [13].

4. Carbon dioxide is an asphyxiant and acetal that may cause skin irritation [3].

5. Propylene glycol ethers are dermal, ocular and respiratory irritants. Acute exposure to high concentra- tions may affect the central nervous system, as well as cause liver and kidney damage [2,3].

6. Siloxane is a dermal and ocular irritant. Exposure to high concentrations of siloxane may cause effects on the reproductive system [3].

7. N-propyl bromide is a central and peripheral neurotoxic. It may cause effects on the reproductive system [3].

Perchloroethylene, besides being able to cause serious poisoning in exposed workers, is a very persistent substance in the environment (ambient air, indoor air, soil, drinking water and groundwater), being an important risk factor for the health of the general population [14]. The International Agency for Research on Cancer (IARC) classified perchloroethylene as being probably carcinogenic to humans (group 2A) on the basis of sufficient evidence in animals and limited evidence in humans [14].

Different international organizations and research groups have proposed the substitution of perchloroethylene by other industrial substances or processes in order to avoid or minimize the risks that perchloroethylene may cause to workers as well as to the general population [1-3].

If perchloroethylene cannot be replaced, special attention should be paid to providing the workers exposed with the necessary information and training; environmental inspections of each workspace must be performed, and specific health surveillance measures must be taken in order to prevent (or at least minimize) the negative health effects of this chemical agent.

\section{CONCLUSIONS}

Perchloroethylene is a solvent widely used in the workplace.

Perchloroethylene may cause acute severe poisoning and chronic poisoning, and the IARC has classified it as a probable carcinogen in humans.

Therefore, before using perchloroethylene, its possible substitution by other less toxic substances should be investigated..

\section{REFERENCES}

1. Toxics Use Reduction Institute. Categorization of the toxic use reduction list of toxic and hazardous substances. Methods and policy report No. 18 [Internet]. Lowell: University of Massachusetts; 1999 [cited 2018 May 3]. Available from: http://www.turi.org/content/download/3458/42966/file/1999.

2. Oleart Comellas P, Pou Serra R, Rabassó Campí J, Sanz-Gallen P. Guía práctica para la sustitución de agentes quími- 
cos por otros menos peligrosos, en la industria [Internet]. Barcelona: Foment del Treball; 2011 [cited 2018 May 3]. Available from: https://www.researchgate.net/publication/ 318852408_Guia_practica_para_la_sustitucion_de_agentes_quimicos_por_otros_menos_peligrosos_en_la_industria.

3. Toxics Use Reduction Institute. Assessment of alternatives to perchloroethylene for the dry cleaning industry. Methods and policy report No. 27 [Internet]. Lowell: University of Massachusetts; 2012 [cited 2018 May 3]. Available from: http://www.turi.org/TURI_Publications/TURI_Methods_ Policy_Reports/Assessment_of_Alternatives_to_Perchloroethylene_for_the_Dry_Cleaning_Industry._2012.

4. Instituto Nacional de Seguridad, Salud y Bienestar en el Trabajo. Límites de Exposición Profesional para agentes químicos en España 2018. Madrid: Instituto; 2018.

5. Bale AS, Barone S, Scott SC, Cooper GS. A review of potential neurotoxic mechanisms among three chorinated. Toxicol Appl Pharmacol. 2011;255:113-26.

6. Lukaszewski T. Acute tetrachloroethylene fatality. Clin Toxicol. 1979;15:411-5.

7. Levine B, Fierro MF, Goza SW, Valentor JC. A tetrachloroethylene fatality. J Forensic Sci. 1981;26:206-9.
8. Amadasi A, Mastrolura L, Marasciulo L, Caligava M, Sironi L, Gentile G, et al. Death due to acute tetrachloroethylene intoxication in a chronic abuser. Int J Legal Med. 2015; 129:487-93.

9. Shen C, Zhao C-Y, Liu F, Wang Y-D, Wang W. Acute liver failure associated with occupational exposure to tetrachloroethylene. J Korean Med Sci. 2011;26:138-42.

10. Lash LH, Parker JC. Hepatic and renal toxicits associated with perchloroethylene. Pharmacol Rev. 2001;53:177-208.

11. Mckee RH, Adenuga MD, Carrillo JC. Characterization of the toxicological hazards of hydrocarbon solvents. Crit Rev Toxicol. 2015;45:273-365.

12. Kim YW, Kim MJ, Chung BY, Bang DY, Lim SK, Choi SM, et al. Safety evaluation and risk assessment of d-limonene. J Toxicol Environ Health B Crit Rev. 2013;16:17-38.

13. Astier A, Paraire F. Fatal intoxication with 1,1-Dichloro1-Fluoroethane. N Engl J Med. 1997;337:940, https://doi. org/10.1056/NEJM199709253371315.

14. Guyton KZ, Hogan KA, Scott CS, Cooper GS, Bale AS, Kopyler L, et al. Human health effects of tetrachloroethylene key findings and scientific issues. Environ Health Perpect. 2014;122:325-34.

This work is available in Open Access model and licensed under a Creative Commons Attribution-NonCommercial 3.0 Poland License - http://creativecommons.org/licenses/by-nc/3.0/pl/deed.en. 